\title{
Research on the Regulation of Rent-seeking Behavior of PPP Project Government Based on the Whole Life Cycle
}

\author{
Li Mei $^{1}$, Yin Yulin ${ }^{1,2}$, Wang Xiang ${ }^{2}$ \\ ${ }^{1}$ Tianjin University of Technology, Tianjin 300384, China; \\ ${ }^{2}$ Department of Management and Economics, Tianjin University, Tianjin 300072, China
}

Keywords: PPP project government rent-seeking regulation

\begin{abstract}
This paper studies the government rent-seeking behavior in the whole life cycle of PPP project, forms the government-wide rent-seeking map of the whole life cycle of PPP project, provides basis for regulating the government's rent-seeking behavior, and analyzes the key reasons for rent-seeking behavior and proposes the corresponding regulatory path, to establish a road map of government rent-seeking behavior in the life cycle of PPP projects, and to provide guidance for regulating PPP project government rent-seeking behavior.
\end{abstract}

\section{Introduction}

Although PPP projects are in full swing in recent years, in the process of PPP project promotion, because the supervision system is still not perfect, plus the common areas of PPP are infrastructure and public utilities construction, the probability of rent-seeking in these areas itself It is bigger. If the two are superimposed, the rent-seeking problem in the PPP project should be taken seriously. Therefore, the PPP project can be regulated by studying the rent-seeking problem in the PPP project.

With the emergence of rent-seeking behavior, the attention of social capital has shifted from production innovation and management innovation to rent acquisition, disrupting market order, distorting the allocation of social resources, causing unfair competition, and rent-seeking behavior is not stopped in time, which may lead to Corruption is prevalent, damaging the image of the party and the government, which seriously interferes with and affects the economic development of society. Therefore, it is imperative to regulate government rent-seeking behavior in PPP projects.

Based on the above hazards, this study will explore the government's rent-seeking behavior regulation throughout the life cycle of PPP projects, study the performance of rent-seeking points and government rent-seeking behaviors throughout the life cycle of PPP projects, and target government rent-seeking behaviors that lead to the full life cycle of PPP projects. The key reasons are to propose corresponding regulatory paths, break the rent-seeking conditions, and solve the government rent-seeking problem in the whole life cycle of PPP projects, improve the fairness of project competition, improve the efficiency of project operation, and ensure the standardized and healthy development of PPP projects.

\section{Literature Review}

\subsection{PPP government rent-seeking study}

Without the intervention of the government, any excess profits in the market will gradually disappear with the participation of competitors. Only under the intervention and regulation of the government, the trend of the decline or disappearance of such excess profits will be artificially controlled. Only the company has a rent to find. It can be seen that the phenomenon of rent-seeking is accompanied by government behavior from beginning to end. As far as PPP projects are concerned, the government has the power to grant PPP project franchise rights, and the current PPP project laws and regulations and supervision mechanisms are imperfect, and potential social capital "tempted" the government to obtain rent-seeking behavior in order to obtain franchise rights. Chen 
Hong analyzed the real paradox between PPP project supervision and rent-seeking in China. By establishing a game model of rent-seeking and supervision of PPP projects, the paper proposes an institutional solution to the dilemma of rent-seeking and supervision. Coincidentally, Yu Yuye analyzed some of the government rent-seeking behaviors in the PPP project through case studies, and analyzed the foreign PPP model power rent-seeking prevention mechanism, and proposed the construction of China's PPP model power rent-seeking prevention mechanism. Similarly, Cao Qilong concludes that by establishing a game model of rent-seeking by the project company and government-incentive supervision, the government can optimize the revenue by strengthening the punishment, thereby indirectly restraining the government's rent-seeking behavior. By discussing the incompleteness of the contract and the degree of corruption of government officials drafting the contract, Elisabetta Iossa further proposed that the government's discretion should be reduced in the process of drafting the contract. On this basis, Hu Zhenhua pointed out from the perspective of administrative law that the current PPP project in China is prone to government power rent-seeking and corruption, and proposes to strictly regulate the phenomenon of rent-seeking in law, and to guide the public and private parties in thought. Eliminate rent-seeking behavior.

In summary, the current research on government rent-seeking for PPP projects is distributed in contract management, government supervision, PPP project bidding, risk sharing and management. It indicates that the government rent-seeking problem in PPP projects has become the focus of academic circles. It has been realized that the government rent-seeking is an important factor to undermine the benign development of the PPP project market, and has proposed a corresponding regulation mechanism for rent-seeking behavior in a certain part of the PPP project, but lacks a coherent PPP project life-cycle government rent-seeking behavior. Related research.

\subsection{Research on rent-seeking regulation}

From the perspective of legal regulation, Zhang Jian proposed the regulation methods for government rent-seeking behavior in China's economic transition period, such as improving relevant national laws and regulations, improving the government's administrative open system and government administrative examination and approval system. Wu Hao's research has led to the reasons for China's power rent-seeking phenomenon, such as limited resources, weak government power constraints, imperfect institutional systems, and imperfect systems. Regulating power rent-seeking should achieve power in the sun and improve power constraints and supervision. mechanism. Zhou Chen believes that the legal regulation of rent-seeking behavior should be regulated by law-based administration, increasing transparency of government behavior, improving the quality of administrative personnel, and strengthening supervision over administrative power. "Unexpectedly, Yu Yuye through the case analysis of the performance of government power rent-seeking behavior in the PPP project, that the lack of supervision, misplacement, unclear definition of the object of supervision and the lack of moral restraint mechanism are the main reasons for government power rent-seeking, and In the same way, Chen Hong analyzed the dual role of China's PPP government. By establishing a game model of PPP rent-seeking and supervision, the paper proposes an institutional solution to the problem of rent-seeking and supervision, such as accelerating PPP legislation and improving PPP supervision mechanism.

Therefore, the regulation of rent-seeking behavior includes improving the system, strengthening supervision, and achieving information transparency. This paper provides research ideas for this paper, but the corresponding literature lacks in-depth analysis of countermeasures and recommendations for implementation, and is based on the life of PPP projects. From the perspective of cycle, the study of government rent-seeking behavior regulation is a minority, and its countermeasures are theoretically strong and lack practical significance. This study will analyze the causes of government rent-seeking behavior from the perspective of the life cycle of the PPP project, and propose a regulatory path that can be implemented.

\section{Solutions to PPP Project Life Cycle Government Rent-seeking Behavior}

The identification, analysis and regulation of rent-seeking problems are very common in the field 
of traditional construction engineering, but they are limited to bidding and project quality supervision. They are not analyzed from the perspective of the whole life cycle, and there is no rent-seeking for PPP projects. Special research. In order to solve the above problems, this paper solves the above problems from the perspective of rent-seeking theory from the perspective of the whole life cycle. The specific idea is the identification, analysis and regulation of rent-seeking points.

This paper adopts the literature review method, which provides the basis and support method for the research through the contents of the literature. Through the literature review method, the rent-seeking point of the whole life cycle of PPP project is identified, and the government rent-seeking behavior in the whole life cycle of PPP project is further analyzed. Then, based on the performance of the PPP project life-cycle rent-seeking point and rent-seeking behavior, the reasons for the above-mentioned government rent-seeking behavior are analyzed. After finding the reason for the government to seek rent, the next step is the construction of the regulatory path. The construction of the regulatory path is based on the analysis of the loopholes in each of the key reasons for the government's rent-seeking behavior throughout the life cycle of the PPP project. The corresponding regulatory methods are proposed for each vulnerability of each cause, breaking the conditions that encourage the government to seek rent., to construct a PPP project life cycle government rent-seeking behavior regulation path map.

\section{Reasons for Rent-seeking Point Identification and Rent-seeking Behavior in the Whole Life Cycle of PPP Project}

\subsection{PPP project life cycle rent-seeking point identification}

According to the decomposition of the government work process and main work contents of the PPP project life cycle, according to the description of the work content corresponding to each link of the government work, and using the literature review method to adjust the PPP project life cycle government work link and tick and determine The rent-seeking point that exists within the life cycle of a PPP project. The specific analysis process is shown in Table 1.

\subsection{Causes of government rent-seeking behavior in the whole life cycle of PPP projects}

This study mainly analyzes the external causes of rent-seeking behaviors, and analyzes the causes of government rent-seeking behaviors based on the performance of various government rent-seeking behaviors throughout the life cycle of PPP projects. The reasons for rent-seeking are: 1) PPP project laws and regulations and institutional mechanisms are not perfect; 2) lack of sound credit evaluation system, serious breach of trust; 3) lack of public participation mechanism; 4) corruption in the construction market environment is prevalent; 5) The boundaries of government intervention are not clear; 6) the experts of the review are not professional and the evaluation system is not sound; 7) the lack of a complete information disclosure system, the information is opaque; 8) the main stakeholders are driven by economic interests; The disciplinary mechanism is not perfect, and the punishment for rent-seeking is not enough; 10) entrusted agency and information asymmetry; 11) lack of social morality; 12) imperfect regulatory mechanism, serious lack of prior supervision mechanism; 13) lack of PPP project audit; 14) Low rent-seeking cost, low risk, and strong concealment; 15) conflicts in the content of documents issued by various ministries.

\section{Regulation Path of PPP Project Life Cycle Government Rent-seeking Behavior}

\subsection{Optimize the legal environment and improve institutional constraints}

\subsubsection{Accelerate legislation and coordinate the legal system of PPP projects}

In view of the lack of specific legislation for PPP projects, the first thing is to clarify and establish the functional organs responsible for the legislation of PPP projects, and accelerate the initiation of the legislative work of PPP projects in order to solve the problem of conflicts between the subordinate laws caused by the lack of superior laws. Due to the current disputes between the 
National Development and Reform Commission and the Ministry of Finance in the legislative work, the State Council may take the lead and set up a special legislative body to be responsible for and coordinate the legislative work of PPP projects, thereby reducing disputes, promoting PPP project legislation as soon as possible, and promoting the legal construction of PPP projects.

In the process of advancing unified legislation, we must also pay attention to the existing policies and regulations to support the PPP project legislation, coordinate and co-ordinate the PPP project policy documents issued by various departments, and further integrate the legal documents with existing policies and regulations. Convergence, this is the basis for further improving the legal system of the PPP model.

\subsubsection{Improve the system to fill the PPP top design vacancies}

In the legislative process, it is necessary to strengthen the clear regulation of the project preparation, project identification, project procurement, project execution, project handover and the rights and obligations of relevant stakeholders, and further clarify the division of labor, coordination and approval between the various executive departments. , supervision and other issues.

1) At the project identification stage, focus on the process of project initiation, project selection and project decision-making, the main body of responsibility, the key points of screening, and the scope of project selection. Secondly, the accountability system for government decision-making mistakes should be established, and government officials should be strengthened. Responsibility in the early stages of the project, refine the working procedures and responsible subjects.

2) In the project preparation stage, the guidance documents should be refined and supplemented for the three aspects of programming, project demonstration and program approval.

3) The procurement stage of the project is mainly to realize the selection of social capital, and to stop the occurrence of government rent-seeking behavior from the source. First, it is necessary to subdivide the classification criteria and strengthen the supervision of the participants in the procurement process. Secondly, improve the government's supervision functions and mechanisms for the procurement process, and implement the supervision of the key links in the whole process of procurement as much as possible. Finally, it is necessary to clarify the participation. The party's legal responsibility should not only emphasize the pursuit of personal responsibility, but not just the responsibility of the company.

\subsection{Strengthen public supervision and build a participatory mechanism}

\subsubsection{Improve the public participation mechanism}

To establish a sound public participation mechanism, it is necessary to clarify the public participation stage, the participants and the responsibilities of the main body, the participation methods of the main body, etc. The public participation mechanism should run through the whole process of the PPP project.

1) PPP project identification phase and preparation phase

In the PPP project identification and preparation stage, the public mainly focuses on the project's investment risk, project social benefits and public benefits. Since the public is the actual beneficiary of the project, and early participation can better understand the public needs, the public participation in the decision-making stage can effectively avoid decision-making mistakes, reduce conflicts between stakeholders in the decision-making process, reduce and prevent The occurrence of corruption incidents in project decisions. Based on the consideration of public needs and professional needs of decision-making, it is recommended that the public participation participants at this stage include: residents around the project, experts in related fields, and news media.

2) PPP project construction stage

In the PPP project construction phase, the public is most concerned about whether the project quality is qualified. Compared with the construction preparation stage and the construction stage, the rent-seeking behavior of the project quality supervision department is degraded, and the project payment settlement fraud is easy to occur during the completion acceptance stage. The introduction of public participation in the completion acceptance stage can strengthen the supervision of project 
quality and objectively reflect the environmental pollution and ecological damage of the project construction. Based on this, the main participants in this stage include: experts in related fields, project users, and news media.

3) PPP project operation phase and handover phase

In the PPP project operation phase and handover phase, the public is mainly concerned with the quality of the project's operational services. The public participants and responsibilities are generally the same. It is recommended that the participants include: project users, relevant field experts and news media.

\subsubsection{Strengthen public awareness}

To establish a public supervision mechanism, we must first establish a smooth communication channel to ensure the openness and transparency of information is the basis for public participation in supervision. Second, we must strengthen the people's legal awareness and participation.

\subsubsection{Strengthen public opinion supervision}

Public opinion supervision is called "the fourth kind of power" by Jefferson, and it is a sword that restricts power. Strengthening public opinion supervision can not only solve the problem of information asymmetry in the process of PPP project operation, but also improve the social supervision system of PPP project. At the same time, it is of great significance to establish a perfect public participation supervision mechanism for PPP projects. Based on the above points, the following measures can be taken to strengthen public opinion supervision:

(1) Standardize the supervision mechanism of public opinion

(2) Accelerate the legislation of the news, so that the supervision of the news public opinion can be based on

(3) Expanding the scope of rights of the media to be supervised by law

\subsection{Define the right to intervene to prevent abuse of the right to intervene}

Rent-seeking activities occur when the government assumes part of the resource allocation, or in a variety of ways that affects the resource owner's control over and use of its resources. Therefore, excessive government intervention is the source of rent and rent-seeking.

\subsubsection{Clarify the conditions for the exercise of government intervention}

In response to the analysis of the loopholes in government intervention conditions, the regulatory methods are as follows:

1) In the case of government intervention in the case of non-default of the project company, it is recommended to provide detailed regulations on the size, scope and extent of the incidents that endanger the risks to the person, property and the environment, so as to prevent possible government rent-seeking behaviors in this link. .

2) The definition of "emergency" is unclear, giving the government greater power to exercise the right to intervene, and it is easy to generate rent-seeking behavior. Therefore, it is recommended to give reasonable judgment criteria for emergencies.

3) In case the project company defaults. There is a lack of provisions on government intervention conditions. In order to prevent government rent-seeking behavior, it is recommended to join the government to exercise the right to intervene.

\subsubsection{Standardizing the procedures for the exercise of government intervention}

1) Increase the notification procedure in the government's right to intervene

When the government side exercises the right of intervention, it must inform the project company in advance because the advance notice procedure means that the project company in the PPP project has an independent interest and cannot be arbitrarily controlled to limit the government's abuse of the right to intervene as much as possible.

In the "PPP Project Contract Guide (Trial)" (Financial [2014] No. 156), the notification procedure of government intervention is stipulated only in the case of project company default, and 
does not include the notification procedure under the case that the project company has not breached the contract. In addition to notifying the procedures, there is still a lack of corresponding notification content and exercise basis. Therefore, the following suggestions are made: First, at the start-up phase of the intervention, the government should inform the project company in writing of the reasons for the intervention, the basis of the law or contract, and the main body. Matters such as time, place and method, and the time limit for correction should also specify the corrections and the time for correction. Second, in the case of special crisis, the relevant personnel who exercise the right of intervention should present the corresponding certification documents and certificates. The main staff of the project company will intervene in the presence of the project; the third is that when the government intervention needs to be transferred back to the project company or other reasons for the termination of the intervention, the government also needs to write the final cause, handover time, handover method, etc. to the project company.

2) Increase the hearing procedure when the government intervenes

The initiation of the government's right to intervene includes the involvement of the project company in the absence of breach of contract and the involvement of the project company in the event of default. The essence of this is that the government has made administrative actions that directly affect the legitimate rights and interests of the project company. To prevent the abuse of the right to intervene, it is recommended to increase the hearing procedure for the government's right to intervene and give the project company, interested parties and other hearing rights. In addition, if there is a case where the project company applies to the government for intervention, the government needs to investigate the project company and decide whether to intervene. It is even more necessary to increase the hearing procedure to verify whether the request made by the project company is reasonable.

\subsection{Strengthen information disclosure and weaken information opacity}

\subsubsection{Establish a challenge complaint mechanism}

In the implementation process of PPP projects in China, it is necessary to ensure the effective implementation of information disclosure. It is essential to establish a system for questioning complaints, including the clear reply procedure for the disclosure of application information and the procedure for applying for complaints.

\subsubsection{Define the scope of sensitive information}

It is recommended to clarify the most basic sensitive information standards in the guidance document. In addition, because different types of contracts and different types of providers have different sensitive information, China should also learn from international experience and clearly define and refine it through negotiation. Sensitive information should fully discuss each of the factors in the project that may constitute sensitive information, such as methods and elements of price formation, basic financial models, and special arrangements in the project transaction structure.

\subsubsection{Strengthen the information verification mechanism}

The relevant government department, project implementation agency or project company is the implementer and responsible person of the project information disclosure, and is responsible for the quality of the project information. In order to ensure the timeliness, authenticity and accuracy of the project public information, it should be within the government or Hire a third-party professional organization to verify information and establish an information review and verification mechanism. For example, the relevant laws of New South Wales, Australia require independent verification by a third party before the PPP project information is published.

\subsection{Increase the cost of rent-seeking and increase the punishment}

\subsubsection{Improve the private cost of rent-seekers}

1) The countermeasures for low rent-seeking costs for government officials are: increasing 
rent-seeking costs, increasing policy deterrence, and increasing penalties, making rent-seeking a high-cost, high-risk activity, thereby reducing government search to a certain extent. The possibility of a rental activity.

2) The study found that the probability of the government's external economy (ie, the enterprise) conducting the rent-seeking investigation is far lower than the probability that the government officials will be disciplined by the party discipline due to the investigation of rent-seeking behavior. The countermeasures against low private cost of social capital rent-seeking are: raising the private cost of social capital rent-seeking, reducing the possibility of collusion with the government, establishing a broad credit mechanism, and increasing penalties and management mechanisms for social capital. Thereby indirectly reducing government rent-seeking behavior.

\subsubsection{Establish a rent-seeking disciplinary prevention mechanism}

In order to prevent things from developing, they should be contained at the source. Therefore, for the government rent-seeking behavior, a rent-seeking and zero-tolerance system should be established. Once the rent-seeking behavior is discovered, regardless of the severity of the incident, the relevant personnel should be punished accordingly, forming a preventive and disciplinary mechanism for public officials who are not daring to greedy; To play the educational preventive role of the disciplinary mechanism.

\subsection{Set up an independent regulatory body to increase supervision}

\subsubsection{Establish a comprehensive independent regulatory agency}

1) Classification of PPP project supervision departments

As far as the current PPP project supervision department is concerned, the financial department, the construction department, the auditing agency, the environmental protection department, the fire department, the civil defense department, the land management department, the supervisory authority, and other administrative departments have been sorted out by the PPP project supervision department. It is divided into four categories: traditional regulatory authorities (referring to government investment authorities, construction departments, financial departments, etc.), audit departments, supervision departments, and comprehensive independent regulatory agencies.

2) Establish a comprehensive independent regulatory agency

In order to ensure the unified and continuous supervision of the whole process of PPP projects and the transparency and transparency of regulatory information, it is recommended to establish a comprehensive independent regulatory body to clarify its responsibilities and powers, and to disclose information on the regulatory results obtained by regulatory agencies. The possibility of government rent-seeking for PPP projects.

\subsubsection{Construct an evaluation system for regulatory performance}

In view of the current government Prent-seeking behavior caused by the unclear division of duties and responsibilities of the regulatory agencies in China, the lack of prior supervision mechanisms, and the lack of a scientific and unified government supervision performance evaluation system, the regulatory path is proposed: A comprehensive independent regulatory body that clarifies its responsibilities and powers, and focuses on strengthening the pre-regulation of PPP projects to fill the regulatory gaps in the early stage of project identification and preparation; 2 constructing a performance evaluation system for PPP project supervision, according to supervision Performance standards form incentives and accountability mechanisms for regulators to achieve the purpose of regulating government rent-seeking behavior of PPP projects.

\section{Conclusion}

This paper starts from the whole life cycle of PPP project, clarifies the performance of government rent-seeking behavior in the whole life cycle of PPP project, analyzes the key causes of the life-cycle rent-seeking behavior of PPP project, and proposes each rent-seeking based on each vulnerability. The regulatory path and method of the condition finally form a road map for the 
government's rent-seeking behavior in the life cycle of the PPP project, and provide specific suggestions and methods for regulating the government rent-seeking behavior of the PPP project.

\section{References}

[1] Chen Hong,Huang Xiaotong,Guo Dan.Government and Social Capital Cooperation (PPP): Rent-seeking Game and Regulatory Countermeasures[J].Financial Research,2014(10):20-24.

[2] You Yuye.Construction of power rent-seeking prevention mechanism in China's PPP model [D].Wuhan: Wuhan University, 2017.

[3] Cao Qilong, Sheng Zhaobiao, Zhou Jing, Li Qian.The PPP Project Rent-seeking Behavior and Incentive Supervision Model from the Perspective of Contract[J].Science Decision Making,2015(09):51-67.

[4] Elisabetta Iossa,David Martimort.Corruption in PPPs, incentives and contract incompleteness [J].International Journal of Industrial Organization,2016,44:85-100.

[5] Hu Zhenhua. Study on the Difficulties and Countermeasures of Public-Private Cooperation Behavior_—From the Perspective of Administrative Law [D]. Nanchang: Jiangxi University of Finance and Economics, 2013.

[6] Zhang Jian.The Legal Regulation of Government Rent-seeking Behavior in Economic Transition Period [J].Economic Review, 2011(11):71-72.

[7] Wu Wei.Power Rent-seeking and Its Regulation [J].Journal of Hunan Medical University (Social Science Edition), 2008, 10(01):29-31.

[8] Zhou Chen.Government Regulation and Enterprise Rent-seeking-Analysis of Production Behavior Based on Mineral Resources Mining Enterprises [J].Soft Science, 2014, 28(10):60-64.

[9] Ye Xiaosu,.Study on the Public Participation Mechanism of PPP Project[J].Building Economy,2016,37(03):32-36.

[10] Wang Baoxue,Cheng Wei.Analysis of Engineering Project Management Problems Based on Rent-seeking Theory[J].Journal of Engineering Management,2013,27(01):34-38.

[11] Meng Wei, Zhou Lanping. Let PPP develop in the sun to make PPP chaos incomprehensible_A Review of the Interim Measures for the Administration of Information Disclosure of the Government and Social Capital Cooperation (PPP) Integrated Information Platform[J]. China Building Decoration, 2017

[12] A. Kruger, Liu Liming. Political Economy of Rent-seeking Society [J]. Economic and Social System Comparison, 1988(5): 8-16. 
Table 1 PPP project life cycle rent-seeking point identification

\begin{tabular}{|c|c|c|c|c|c|}
\hline $\begin{array}{c}\text { Serial } \\
\text { number }\end{array}$ & stage & Work link & $\begin{array}{l}\text { Work link } \\
\text { adjustment }\end{array}$ & $\begin{array}{c}\text { Whether it is a } \\
\text { rent-seeking } \\
\text { point }\end{array}$ & Rent-seeking point subdivision \\
\hline \multirow{3}{*}{1} & \multirow{7}{*}{$\begin{array}{c}\text { Project } \\
\text { identification } \\
\text { phase }\end{array}$} & \multirow{3}{*}{$\begin{array}{l}\text { Project initiation, } \\
\text { screening and } \\
\text { decision making }\end{array}$} & \multirow{3}{*}{$\begin{array}{c}\text { Project initiation, } \\
\text { screening and } \\
\text { decision making } \\
\end{array}$} & \multirow{3}{*}{$\sqrt{ }$} & Project initiation \\
\hline & & & & & Project screening \\
\hline & & & & & Project decision \\
\hline 2 & & $\begin{array}{c}\text { Implementing } \\
\text { agency authorization }\end{array}$ & \multirow{4}{*}{$\begin{array}{c}\text { Preliminary work } \\
\text { preparation and } \\
\text { due diligence } \\
\text { stage }\end{array}$} & $x$ & \\
\hline 3 & & $\begin{array}{l}\text { Establish a project } \\
\text { coordination } \\
\text { promotion agency }\end{array}$ & & $x$ & \\
\hline 4 & & $\begin{array}{c}\text { Project output } \\
\text { description } \\
\text { preparation } \\
\end{array}$ & & $x$ & \\
\hline 5 & & $\begin{array}{c}\text { Preliminary } \\
\text { implementation plan }\end{array}$ & & $\times$ & \\
\hline 6 & \multirow{6}{*}{$\begin{array}{l}\text { Project } \\
\text { preparation } \\
\text { stage }\end{array}$} & $\begin{array}{c}\text { Detailed } \\
\text { implementation plan }\end{array}$ & \multirow{2}{*}{ Programming } & \multirow{2}{*}{$\sqrt{ }$} & \multirow{2}{*}{ Programming } \\
\hline 7 & & $\begin{array}{l}\text { Value for money } \\
\text { evaluation report }\end{array}$ & & & \\
\hline \multirow[t]{2}{*}{8} & & $\begin{array}{c}\text { Value-for-money } \\
\text { qualitative } \\
\text { evaluation and } \\
\text { implementation plan } \\
\text { demonstration } \\
\end{array}$ & \multirow{3}{*}{$\begin{array}{l}\text { Demonstration } \\
\text { program }\end{array}$} & \multirow{3}{*}{$\sqrt{ }$} & \multirow{3}{*}{ Demonstration program } \\
\hline & & $\begin{array}{l}\text { Modifications to the } \\
\text { implementation plan } \\
\text { and value for money } \\
\text { report }\end{array}$ & & & \\
\hline 10 & & $\begin{array}{c}\text { Financial } \\
\text { sustainability report } \\
\end{array}$ & & & \\
\hline 11 & & Program approval & Program approval & $\sqrt{ }$ & Program approval \\
\hline \multirow[b]{2}{*}{12} & \multirow{6}{*}{$\begin{array}{c}\text { Project } \\
\text { procurement } \\
\text { phase }\end{array}$} & \multirow{2}{*}{$\begin{array}{c}\text { Publish purchase } \\
\text { announcements and } \\
\text { procurement } \\
\text { documents }\end{array}$} & Tendering stage & \multirow[b]{2}{*}{$\sqrt{ }$} & Tendering \\
\hline & & & Bidding stage & & Bidding \\
\hline 13 & & $\begin{array}{c}\text { Determine the } \\
\text { winning social } \\
\text { capital }\end{array}$ & & \multirow{3}{*}{$\sqrt{ }$} & \multirow{3}{*}{$\begin{array}{c}\text { Bid Opening, Bid Evaluation, } \\
\text { and Bid }\end{array}$} \\
\hline 14 & & $\begin{array}{l}\text { Publish the results of } \\
\text { the pre-winning bid } \\
\text { and the } \\
\text { memorandum of } \\
\text { negotiation }\end{array}$ & $\begin{array}{c}\text { Bid Opening, Bid } \\
\text { Evaluation, and } \\
\text { Bid }\end{array}$ & & \\
\hline 15 & & $\begin{array}{l}\text { Successful bidding } \\
\text { results } \\
\end{array}$ & & & \\
\hline 16 & & $\begin{array}{c}\text { Signing a PPP } \\
\text { project contract }\end{array}$ & $\begin{array}{c}\text { Contract signing } \\
\text { phase }\end{array}$ & $\sqrt{ }$ & Contract signing phase \\
\hline \multirow[b]{3}{*}{17} & \multirow{5}{*}{$\begin{array}{c}\text { Project } \\
\text { execution } \\
\text { phase }\end{array}$} & \multirow[b]{3}{*}{$\begin{array}{l}\text { Establish a project } \\
\text { company }\end{array}$} & \multirow{3}{*}{$\begin{array}{c}\text { Project } \\
\text { company } \\
\text { establishment } \\
\text { and preliminary } \\
\text { preparation } \\
\text { stage } \\
\end{array}$} & $\sqrt{ }$ & Financing management stage \\
\hline & & & & & Land acquisition \\
\hline & & & & & Design link \\
\hline 18 & & $\begin{array}{l}\text { Signing a PPP } \\
\text { project contract }\end{array}$ & $\begin{array}{c}\text { Construction } \\
\text { phase }\end{array}$ & $\sqrt{ }$ & Construction phase \\
\hline 19 & & Supervision & $\begin{array}{c}\text { Operational } \\
\text { stage }\end{array}$ & $\sqrt{ }$ & Operational stage \\
\hline 20 & \multirow{5}{*}{$\begin{array}{c}\text { Project } \\
\text { handover } \\
\text { phase }\end{array}$} & $\begin{array}{l}\text { Project transfer } \\
\text { project }\end{array}$ & $\begin{array}{l}\text { Project transfer } \\
\text { project }\end{array}$ & $x$ & \\
\hline 21 & & $\begin{array}{c}\text { Preparation of a } \\
\text { handover plan }\end{array}$ & $\begin{array}{l}\text { Preparation of a } \\
\text { handover plan }\end{array}$ & $x$ & \\
\hline \multirow{2}{*}{22} & & \multirow{2}{*}{$\begin{array}{l}\text { Performance testing } \\
\text { and asset valuation }\end{array}$} & & $\sqrt{ }$ & Performance Testing \\
\hline & & & & & Asset valuation \\
\hline 23 & & Asset delivery & Asset delivery & $\sqrt{ }$ & Asset delivery \\
\hline
\end{tabular}

